\title{
EDITORIAL
}

\section{Innovation in Developing Economies Organizations}

\author{
PhD. Isabella Francisca freitas Gouveia de Vasconcelos ${ }^{1}$ \\ PhD. HÉlio ARTHUR Reis IRIgaraY ${ }^{1}$
}

${ }^{1}$ Fundação Getulio Vargas / Brazilian SChool of Public and Business Administration, Rio de Janeiro - RJ, Brazil

Several authors address the emergence of a new socioeconomic structure arising from the restructuring of the capitalistic production mode. This phenomenon represents the transition from the industrial to the post-industrial production model, when productivity is associated with the generation, processing, accumulation, and utilization of knowledge in technologysupported processes. Within this transitional context, the theme of organizational change and its relationship with people management stand out in the academic scene, and many authors have been discussing these issues, emphasizing their ambiguities and contradictions (CASTELLS, 1999).

The transition between socioeconomic contexts and the recent relevance of the theme of organizational change bring several topics to light, such as the ways individuals construe and operate changes to their working conditions and how these changes affect the meanings people assign to their realities, to their work, and to themselves.

Digital transformation and technological innovation are realities and will dramatically change our society.

In this thematic issue of Cadernos EBAPE.BR, we present several articles that address Digital Transformation and technological change, and the many ways these phenomena are changing society. In addition, this issue features a dossier on Innovation, prepared by the journal's editors PhD. Isabella Vasconcelos, and PhD. Hélio Arthur and the co-authors, Fabiana Braga Leal, Msc, and Leonardo Carvalho, Msc.

We invite you to read this thematic issue's introductory piece, written by Professors Paulo Figueiredo (FGV EBAPE), Roberto Carlos Bernardes (FEI-SP), and Felipe Borine (USP), our guest editors for this issue of Cadernos EBAPE.BR.

We wish all our readers a happy new year 2020 !

PhD. ISABella F. Freitas Gouveia de VAsconcelos

PhD. HÉlio ARThur Reis IRIgaray

EDITORS-IN-CHIEF

\section{REFERENCE}

CASTELLS, M. The Network Society. Cheltenham: Edward Elgar Publishing, 1999. 
PhD. Isabella Francisca Freitas Gouveia de Vasconcelos

ORCID: https://orcid.org/0000-0001-9109-0475

Doctorat es Sciences de Gestion / HEC - Ecole des Hautes Etudes Commerciales, France (2000); PhD in Human Resource Administration from FGV EAESP (1997), Brazil; Post-Doctorate from Rutgers, The New Jersey State University, USA; Adjunct Professor at FGV EBAPE, Brazil; Researcher at CNAM Conservatoire National D’Arts et Metiers, France. E-mail: isabella.vasconcelos@fgv.br

PhD. Hélio Arthur Reis Irigaray

ORCID: https://orcid.org/0000-0001-9580-7859

PhD in Business Administration from FGV EAESP; Master in Business Administration from PUC-Rio and Bachelor Degree in Economics from the University of Northern lowa, USA. Assistant Professor at FGV EBAPE and at the Corporate International Masters (CIM) program of the Georgetown University, Washington, USA. Leader researcher on the theme Diversity and Labor Relations, in the area of Work Management of the National Association of Graduate Studies and Research in Administration (ANPAD). E-mail: helio.irigaray@fgv.brTIROLE, J. Economics for the Common Good. Princeton: Princeton University Press, 2017 